\title{
Impacts of EU Enlargement Process: A Gravity Model Approach
}

\author{
Ildiko Virag-Neumann \\ MTA-PE (Hungarian Academy of Sciences-University of Pannonia) Networked \\ Research Group on Regional Innovation and Development Studies, Hungary \\ University of Pannonia, Faculty of Economics, Department of International \\ Economics, Hungary
}

\section{Abstract}

The approach based on the law of gravity for the study of international trade flows has been widely used in recent years. Gravity model based studies have achieved empirical success in explaining various "flows", for example international trade. Due to simplicity, high explanatory ability and improved econometrics the model is convenient as an examination tool for the researchers. The objective of this research is to provide an overview of the EU enlargement process in the period between 2000 and 2010 by means of a gravity model, as well as to estimate and measure the trade growth as a consequence of the opening up of the trade in the EU. Analysing the trade prospects for the new EU member states is important in the context of European enlargement. My research question is the following: what was the effect of EU enlargement on trade within and outside the EU?

I find that the EU enlargement has large and significant effects on both old and new members' trading activities. Old and new members both increased their exports; new members decreased their imports from the rest of the world. The relevant source of novelty to research lies in the methodology of the econometric model.

Keywords: EU economic integration, gravity model of trade, panel estimation, economy, research

JEL classification: F15, O52

\section{Introduction}

The Eastern enlargement of the European Union constituted an outstanding event in European history, making the EU a unified market of 28 countries with a high degree of economic integration. This is a unique process not only in Europe but also in the world, since there has not been any such integrative cooperation yet to go as far as that. Still Bussière, Fidrmuc and Schnatz (2005) did not expect a large increase in trade due to the integration of Eastern European countries since before the enlargement; this region was well integrated with the Union. Similarly Bchir et al (2003) use a Computable General Equilibrium (CGE) model to explore the impact of enlargement as far as welfare, wages and trade concerned. They forecasted that the trade impacts would be mildly negative (in 2005) for total exports (except in Poland and the Baltic states) and positive for total imports (except in the Baltic States.)

Contrary to previous findings, in this paper I look at the effect of the Eastern enlargement on trade within and outside the EU. I show that the enlargement had important impacts on the structure and orientation of trade both in the new member states and the EU15. Trade has grown very quickly both within the EU12 region and between that region and the EU15. Thus, EU-membership has had a strong effect on 
intra-EU and extra EU trade flows. In order to measure the impact of EU enlargement in the most precise way possible, I use panel data between 2000 and 2010 of 27 EU countries (EU-15, EU-12) and 219 "world countries", a standard gravity model, and a difference-in-difference estimation strategy. My approach allows me to identify all the effects of EU enlargement on old and new members from a single fixed-effect specification with membership dummies. As a consequence, I can avoid various issues that were shown to cause biased estimates in gravity models (multilateral resistance, correlation across dummies)

The paper is structured as follows: The first section is the introduction and presents the hypotheses that are tested at a later stage in order to answer the research question. The second section briefly reviews the different theoretical foundations of the gravity equation, the data collecting and database compiling procedure (Data, variables, specifications of the model).

The third section presents an empirical analysis based on panel data of EU countries in order to check for the above discussed theories with a specific focus on the trade effects of EU membership and the predicted trade effects for the EU entrants with gravity model. After discussing the recent econometric developments in gravity modelling, a correctly specified fixed effects gravity model is proposed. My results will be presented in this section with regard to the typology of EU trade creations. In the final section the main results and consequences are summarized.

\section{Theory of gravity model in international trade}

The gravity model is a mathematical model based on analogy with Newton 'gravitational law which has been used to analyse spatial interaction between two or more points like the gravity in physics (Paas, 2003; Wall - Hui Cheng, 1999). The gravity model of international trade was developed by Jan Tinbergen (1962). It is a multivariate linear regression model for modelling bilateral and regional trade used for analysing cross section and panel data. The model posits that trade between two countries is directly proportional to the "gravitational" pull of their national incomes (GDP), and inversely proportional to the distance between them (Paas, 2003).

The gravity model of trade in international economics predicts bilateral trade flows based on the economic sizes (often GDP measurements) and distance between two units. There are two basic areas of the application of gravitational models based on physical analogy: the spatial flow analysis, and the demarcation of catchment areas." The gravity model has been used widely as a baseline model for estimating the impact of a variety of policy issues, including regional trading groups, currency unions, political blocks, various trade distortions and agreements, border region activities and also historical linkages." (Paas, 2003)

Gravity models are commonly used to investigate trade flows and related policies. Several studies focus on examining the effects of regional trade agreements, currency unions and common markets as well as trade creating or diverting effects other researchers have examined trade policy implications and factors that affect trade, such as natural border effects, monetary union impacts, domino effects, the foreign direct investments, transportation costs. (Kepaptsoglou et al, 2010)

\section{Methodology}

The theoretical considerations for using gravity have been widely discussed and developed and mostly based on microeconomic foundations, trade theories and new economic geography. (Paas, 2003) 
The gravity model of international trade was developed independently by Jan Tinbergen (1962) and Pentti Pöyhönen (1963). Hans Linnemann (1966) included population as an additional measure of country's size. The population expresses the size of a country as well as the size of its economy. Per capita income expresses the level of economic development. Thus, the size of economy and level of economic development are the main attractive forces or pull factors of bilateral trade flows. The main push factor is the distance between the trading partner's countries.

The theoretical considerations for using gravity models to explore international trade flows have been widely discussed and developed. Anderson and van Wincoop (2004) propose an augmented version of the Anderson (1979) model based on the assumption of differentiation of goods according to place of origin. (Gomez Herrera, 2011) Anderson (1979) derives a version of the gravity equation using trade costs and CES preferences and Bergstrand (1985) supported this. Helpman and Krugman (1985) also derived a foundation relying on the assumption of increasing returns to scale where products were differentiated by firms, not only by country, and firms were monopolistically competitive. (Gomez Herrera, 2011)

The main contribution of Anderson and van Wincoop (2003) is the inclusion of multilateral resistance terms for the importer and the exporter that proxy for the existence of unobserved trade barriers.) They made a gravity equation using the generalization with CES preferences. (Gomez Herrera, 2011) They show that exports in gravity equations do not only depend on bilateral trade costs but rather on a ratio of bilateral trade costs and the respective two countries' trade costs to all countries as well. The index that measures a country's overall resistance to trade is called multilateral resistance term. (Gomez Herrera, 2011) The exclusion of the multilateral trade resistance terms leads to biased estimates due to the omission of variables and this misspecification can invalidate the estimation. Bergstrand (1990) provided a foundation based on Dixit and Stieglitz's monopolistic competition assumption.

Another highly influential paper was McCallum (1995). He used the gravity equation to measure the effect of national borders on trade. He concludes that both national borders and bilateral distance are significant frictions to trade. This came at a time when the business press was claiming the "death of distance" and the "borderless world" as world trade became more integrated (Head and Mayer, 2014).

The multiplicative form of the gravity model (Anderson (1979), Bergstrand (1985, 1989), Anderson and van Wincoop (2003)) is the following:

$$
\mathrm{FLOW}_{\mathrm{ij}}=\mathrm{AGDP}_{\mathrm{i}}^{\beta_{1}} \mathrm{GDP}_{\mathrm{j}}^{\beta_{2}} \mathrm{~d}_{\mathrm{ij}}^{\beta_{3}} \mathrm{~L}_{\mathrm{ij}} \mathrm{L}_{\mathrm{i}} \mathrm{L}_{\mathrm{j}} \varepsilon_{\mathrm{ij}}
$$

Taking logs of both sides leads to a log-log model of the form: ${ }^{1}$

$$
\operatorname{lnFLOW} W_{i j}=\ln A+\beta_{1} \operatorname{lnGDP} i+\beta_{2} \operatorname{lnGDP}_{j}+\beta_{3} \operatorname{lnd}_{i j}+\ln L_{i}+\ln L_{j}+\ln L_{i j} \text {. }
$$

A panel database was compiled containing panel of bilateral trade flows for the period 2000-2010 and a cross section and panel data analysis was performed based on a gravity model for estimating the trade value between country-pairs and to compare coefficient estimates for the gravity model of trade to evaluate the effects of EU regional trade integration. In aim of receiving the best regression results from

\footnotetext{
${ }^{1}$ In which FLOW $i j$ is the trade between economy $i$ and $j$ (as reported by economy $i$ ); GDP $i$ is GDP of economy $i$, as a proxy for the size of the reporting economy; GDP $j$ is GDP of economy j, as a proxy for the size of the partner economy; $d i j$ is the distance between $i$ and $j$, as a proxy of travel cost of trade. $L \mathrm{ij} ; \mathrm{L}, \mathrm{i} L \mathrm{j}$, are the predictors, independent variables, stand for other variables such as common language and historical bonds, population, size of the economy; Eij is the residual of the regression
} 
the OLS an alternative version of the standard gravity equation, a fixed effect equation is calculated and run as well.

1. Exports from EU countries to EU countries (2000-2010) within EU member states: The matrix includes bilateral export data, country and country pairs variables, total 7723 observations. One row of the matrix contains variables regarding one country pair (86 cells per line). The matrix comprises a total of 642697 data cells.

2. Export from EU countries to the world's countries: The database contains variables relating country and country pairs: export data to the world's countries between the period 2000 to 2010 totally 63262 observations (data rows) and 154465 cells.

\section{Results}

\section{Exports from EU countries to EU countries (within EU): Gravity empirical estimation results for an EU effect}

Table 1 reports the results of estimates of different panel models, namely the OLS, the fixed effect (FE) and the random effect (RE) models.

Table 1

Gravity panel data regression analysis: Exports from EU countries to EU countries

\begin{tabular}{|c|c|c|c|c|c|c|c|}
\hline \multirow[t]{3}{*}{ Variables } & \multicolumn{7}{|c|}{ Dependent variable: $\ln$ export $_{i j}$} \\
\hline & \multicolumn{7}{|c|}{ Linear regression } \\
\hline & $\begin{array}{l}2000-2008 \\
\text { fixed effect } \\
(f e)(1)\end{array}$ & $\begin{array}{l}\text { 2000-2009 } \\
\text { pool } \\
(O L S)(2)\end{array}$ & $\begin{array}{l}\text { 2000-2009 } \\
\text { random } \\
\text { effect } \\
(\mathrm{re})(3)\end{array}$ & $\begin{array}{l}2000-2009 \\
\text { fixed effect } \\
(f e)(4)\end{array}$ & $\begin{array}{l}2000-2010 \\
\text { pool } \\
(O L S)(5)\end{array}$ & $\begin{array}{l}2000-2010 \\
\text { random } \\
\text { effect }(\text { re })(6)\end{array}$ & $\begin{array}{l}2000-2010 \\
\text { fixed } \\
\operatorname{effect}(f e)(7)\end{array}$ \\
\hline $\ln \mathbf{G D P}_{\mathbf{i}}$ & $\begin{array}{l}1.535^{\text {*** }} \\
(0.459)\end{array}$ & $\begin{array}{l}1.163^{* * *} \\
(0.012)\end{array}$ & $\begin{array}{l}1.125^{* * *} \\
(0.033)\end{array}$ & $\begin{array}{l}1.401^{\text {*** }} \\
(0.114)\end{array}$ & $\begin{array}{l}1.049^{* * *} \\
(0.050)\end{array}$ & $\begin{array}{l}1.264^{* * *} \\
(0.072)\end{array}$ & $\begin{array}{l}1.424^{* * * *} \\
(0.033)\end{array}$ \\
\hline $\ln \mathbf{G D P}_{\mathbf{j}}$ & $\begin{array}{l}1.187^{* * * *} \\
(0.276)\end{array}$ & $\begin{array}{l}0.7623^{* * *} \\
(0.015)\end{array}$ & $\begin{array}{l}0.801^{\text {*** }} \\
(0.310)\end{array}$ & $\begin{array}{l}0.806^{\text {**** }} \\
(0.110)\end{array}$ & $\begin{array}{l}0.889^{* * * *} \\
(0.046)\end{array}$ & $\begin{array}{l}0.866^{* *} \\
(0.068)\end{array}$ & $\begin{array}{l}0.664^{* * * *} \\
(0.310)\end{array}$ \\
\hline $\ln$ DIST $_{\mathrm{ij}}$ & -1.091 & $\begin{array}{l}-1.142^{* * * *} \\
(0.028)\end{array}$ & $\begin{array}{l}-1.102^{* * *} \\
(0.077)\end{array}$ & -1.120 & $\begin{array}{l}-1.049^{* * *} \\
(0.033)\end{array}$ & $\begin{array}{l}-1.097^{* * *} \\
(0.079)\end{array}$ & $\begin{array}{l}-0.675 \\
(0.077)\end{array}$ \\
\hline EU ONE & $\begin{array}{l}0.239^{\text {*** }} \\
(0.010)\end{array}$ & 0.243 & $\begin{array}{l}0.274^{* * * *} \\
(0.054)\end{array}$ & $\begin{array}{l}0.280^{* * * *} \\
(0.049)\end{array}$ & $\begin{array}{l}0.165^{* * *} \\
(0.097)\end{array}$ & $\begin{array}{l}0.293^{\text {**** }} \\
(0.049)\end{array}$ & $\begin{array}{l}0.316^{\text {**** }} \\
(0.054)\end{array}$ \\
\hline EUBOTH & $\begin{array}{l}0.381^{\text {*** }} \\
(0.114)\end{array}$ & 0.432 & $\begin{array}{l}0.574^{* * *} \\
(0.052)\end{array}$ & $\begin{array}{l}0.486^{* * * *} \\
(0.054)\end{array}$ & $\begin{array}{l}0.623^{\text {**** }} \\
(0.105)\end{array}$ & $\begin{array}{l}0.523^{* * *} \\
(0.523)\end{array}$ & $\begin{array}{l}0.545^{\text {**** }} \\
(0.052)\end{array}$ \\
\hline $\mathbf{R}^{2}$ & 0.940 & 0.693 & 0.6208 & 0.615 & 0.705 & 0.702 & 0.670 \\
\hline
\end{tabular}

Note: ${ }^{* * *}$ implies that the estimated coefficient is different from 0 at a $5 \%$ significance level. The relative error of fitting is under $15 \%$.

Source: own compilation

Exporter GDP and importer GDP are positive as expected and significant at $5 \%$. any unit increase of a country's GDP raises, ceteris paribus, its exports to other EU countries by $1.535 \%$ more). The aim is to capture the different impact of European integration on the bilateral trade between EU countries. The main variable of interest is the dummy variable EU which takes a value of one if both countries are a member 
of the European Union and zero otherwise. The estimated coefficient EU membership is positive and has a very high estimated value. The coefficient is also statistically significant at the $5 \%$ level. The impacts of EU membership are all positively significant. The intra-EU trade volumes were positively affected by the enlargement of the European Community with the accession of new member states .In estimating the bilateral trade within the EU seven models were set up according to the panel analysis between 2000 and 2010 (OLS, Random effects (RE) fixed effects (FE)).Dependent variable is log bilateral exports. Country pair fixed effects, exporteryear and importer-year dummies included. According to the panel fixed effect estimation the exporter GDP and importer GDP are positive as expected and significant at 5\% (any unit increase of a country's GDP raises its exports to other EU countries by $1.535 \%$ more). When one country of the country pair is the member of $\mathrm{EU}$ and the other is not then the export raises with $\exp (0.23)=25.6 \%$. When both the countries are members of the EU, the estimated coefficient EU membership is positive and has a very high estimated value of $\exp (0.38)=1.462$. The EU dummy is 0.545 .

Figure 1

Shape of regression: fixed effect estimation 2000-2010
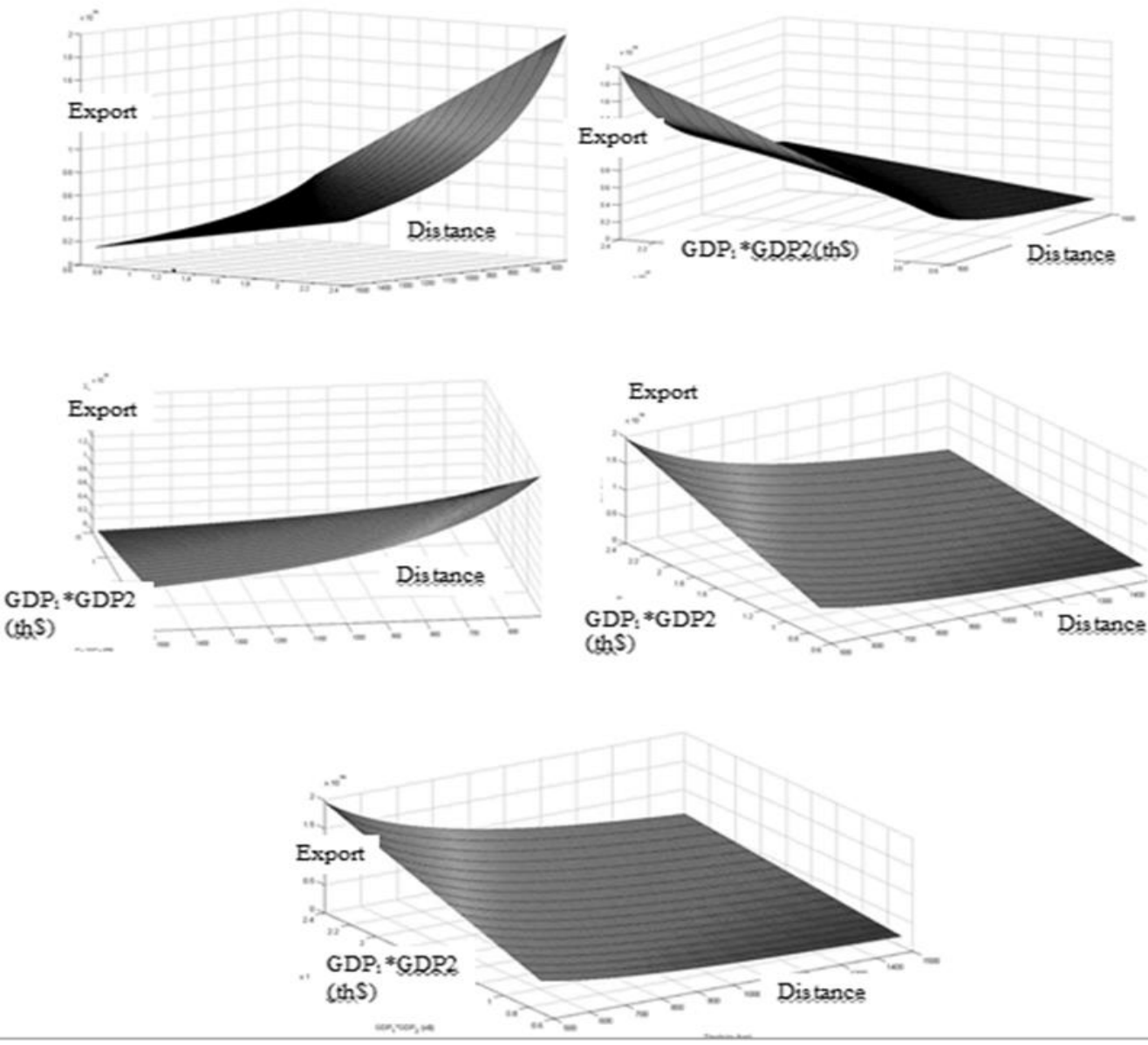

Source: figures are based on own calculation with Mat lab program

The analysis demonstrating the trade between the EU and the rest of the world resulted in the increasing impact of EU trade. The export in the direction of thirdcountry grows by $30.9 \%$ with a country's entry into the EU. When a country enters the EU, the trade coming from the insider EU countries grows by $10.5 \%$ and the export from entering countries to EU countries increases by $24.6 \%$. These results demonstrate 
the increase in trade with insiders and outsiders as well. I use the Hausman Test for choosing between fixed effects and random effects specifications clearly favours FE over RE and is in line with the above mentioned results.

I extend the sample with countries that are outside the EU's customs union. I explicitly follow the difference-in-differences strategy to capture the effect of a policy change. Panel regression results are presented in Table 2.

Table 2

Gravity panel data regression analysis: Export from EU countries to the rest of the world

\begin{tabular}{|c|c|c|c|}
\hline \multirow[t]{4}{*}{ Variables } & \multicolumn{3}{|c|}{$\begin{array}{l}\text { Export from EU countries to the world } \\
\text { Dependent variable: } \ln \text { export }_{i j}\end{array}$} \\
\hline & \multicolumn{3}{|c|}{ Linear regression } \\
\hline & $2000-2010$ & $2000-2010$ & $2000-2010$ \\
\hline & Pooled OLS & Fixed effects & Random effects \\
\hline \multirow[t]{2}{*}{$\ln \mathbf{G D P}_{\mathbf{i}}$} & $1.076^{* * *}$ & $0.445^{* * *}$ & $0.738^{* * *}$ \\
\hline & $(0.005)$ & $(0.026)$ & $(0.123)$ \\
\hline \multirow{2}{*}{$\ln \mathbf{G D P}_{\mathbf{j}}$} & $0.962^{* * * *}$ & $0.622^{* * * *}$ & $0.791^{* * *}$ \\
\hline & $(0.004)$ & $(0.020)$ & $(0.009)$ \\
\hline \multirow{2}{*}{$\underset{\text { distance }_{i j}}{\ln }$} & $-1.089^{* * *}$ & & \\
\hline & $(0.0108)$ & & \\
\hline \multirow[t]{2}{*}{ eu sender } & & $0.273^{* * *}$ & $0.410^{* * *}$ \\
\hline & & $(0.196)$ & $(0.183)$ \\
\hline \multirow[t]{2}{*}{ eu host } & & $0.155^{* * *}$ & 0.411 \\
\hline & & $(0.055)$ & $(0.054)$ \\
\hline \multirow[t]{2}{*}{ eu both } & & $0.374^{* * * *}$ & $0.279^{* * *}$ \\
\hline & & $(0.039)$ & $(0.037)$ \\
\hline \multirow[t]{2}{*}{ border } & $0.802^{* * *}$ & & \\
\hline & $(0.049)$ & & \\
\hline \multirow[t]{2}{*}{ language } & $0.692^{* * *}$ & & \\
\hline & $(0.028)$ & & \\
\hline$R^{2}$ & 0.767 & 0.669 & 0.694 \\
\hline
\end{tabular}

Note: ${ }^{* * *}$ implies that the estimated coefficient is different from 0 at a $5 \%$ significance level. The relative error of fitting is under $15 \%$.

Source: Own compilation

\section{Conclusion}

Although trade was free for most products due to bilateral FTAs between the pre2004 EU and the entrants and among the entrants themselves years before the enlargement, evidence shows that the enlargement brought further trade-creation. I find that the new entrant countries (EU-12) have increased trade not only with the EU member countries but also towards outsiders. On entering the EU the export from entering countries to insider countries increases by $24.6 \%$ in the long run while the trade increases towards the outsiders at a growing pace as well. DID analysis have also supported my claims? I apply robust standard errors in my estimations .In aim of receiving the best regression results from the OLS an alternative version of the 
standard gravity equation, a fixed effect equation is calculated and run as well. I find that the EU enlargement has large and significant effects on both old and new members' trading activities.

I have to take into consideration a correct specification of multilateral resistance terms in a panel data set. With the "difference in differences" technique I have measured the effect of a treatment at a given period in time namely the tradecreating effect of EU. Joining the EU can be quantified by comparing the increase of trade activity of the entrant countries between the pre-entry and the post-entry periods. My results offer evidence for a high positive impact of European integration on trade.

Although this research was carefully prepared, I am still aware of its limitations. First of all, the research was conducted between 2000 and 2010. I leave this subject for further research, the present study can be extended by using a more complete data set after 2010.A longer period will likely lead to interesting results.

Second the evaluation the EU economic integration effects across sectors might give useful information about the impacts of enlargement. Future research could also include a sectoral gravity model which allows us to capture the implicit benefits of EU trade.

\section{References}

1. Anderson, J. (1979), "A Theoretical Foundation for the Gravity Equation", American Economic Review, Vol. 69 No. 1, pp. 106-116.

2. Anderson, J. (2010), "The Gravity Model", NBER Working Paper 16576.

3. Anderson, J., van Wincoop, E. (2004), "Trade Cost", Journal of Economic Literature, Vol. 42.

4. Anderson, J., Marcouiller, D. (2002), "Insecurity and the Pattern of Trade": An Empirical Investigation, Review of Economics and Statistics, Vol. 84 No. 2, pp. 342-352.

5. Anderson, J., van Wincoop, E. (2002), "Borders, Trade, and Welfare", in: Collins, S.M., Rodrik, D. (Eds.), Brookings Trade Forum, Brookings Institution, pp. 207-244.

6. Anderson, J., van Wincoop, E. (2003), "Gravity with Gravitas": A Solution to the Border Puzzle, American Economic Review, Vol. 93, pp. 170-192.

7. Baier, S. L., Bergstrand, J.H. (2005), "Do Free Trade Agreements Actually Increase Members" International Trade?", Federal Reserve of Atlanta, Working Paper 2005/3.

8. Baier, S.L., Bergstrand, J.H. (2001), "The Growth of the World Trade: Tariffs, Transport Costs, and Income Similarity", J Int Econ, Vol. 53 No. 1, pp. 1-27.

9. Bchir, H., Fontagné, L., Zanghieri, P. (2003), "The Impact of EU Enlargement on Member States", A CGE Approach, CEPII Working Papers 10, Paris, CEPII.

10. Buch, C., Piazolo, D. (2001), "Capital and Trade Flows in Europe and the Impact of Enlargement", Economic Systems, Vol. 25, pp. 183-214.

11. Bussière, M., Fidrmuc, J., Schnatz, B. (2005), "Trade integration of Central and Eastern European countries: lessons from a gravity model", Working Paper 545, Frankfurt, European Central Bank.

12. Curran, L., Zignago, S. (2012), " EU enlargement and the evolution of European production networks", Research in International Business and Finance, Vol. 26 Np. 2, pp. 240-257.

13. Gomez, H. (2011), "Comparing alternative methods to estimate gravity models of bilateral trade", ETSG Conference Proceedings 2011, available at: www.etsg.org (accessed June $3^{\text {rd }}$ 2015). 
14. Dixit, A.K., Stiglitz, J.E. (1977), "Monopolistic Competition and Optimum Product Diversity", American Economic Review, Vol. 67, pp. 297-308.

15. Evenett, S., Keller, W. (2002), "On Theories Explaining the Success of the Gravity Equation", Journal of Political Economy, Univ. of Chicago Press, Vol. 110, pp. 281316.

16. Head K., Mayer, T., Thoenig M. (2014), "Welfare and Trade Without Pareto", Sciences Po Economics Discussion Papers, pp. 2014-02, Sciences Po Departement of Economics.

17. Kepaptsoglou, K. Karlaftis M.G, Tsamboulas, D. (2010), "The gravity model specification for modelling international trade flows and free trade agreement effects: a 10-year review of empirical studies", The Open Economics Journal, Vol. 3, pp. 1-13.

18. McCallum, J. (1995), "National Borders Matter: Canada-US Regional Trade Patterns", The American Economic Review, Vol. 85 No. 3, pp. 615-623.

19. Paas, T. (2003), "Regional Integration and International Trade in the Context of EU Eastward Enlargement", HWWA Discussion Papers 218, Hamburg Institute of International Economics (HWWA).

20. Paas, T., Tafenau, E. (2005), "Regional Trade Clusters and Their Role in Promoting EU Enlargement", Transition Studies Review, Vol.1, pp. 77-90.

21. Pöyhonen, P. (1963), "A Tentative Model for the Volume of Trade between Countries", Weltwirtschaftliches Archiv, Vol. 90 No. 1, pp. 93-99.

22. Rose, A.K., van Wincoop, E. (2001), "National Money as a Barrier to International Trade: The Real Case for Currency Union", The American Economic Review, Vol. 91 No. 2, pp. 386-390.

23. Tinbergen, J. (1962), "Shaping the World Economy: Suggestions for and International Economic Policy", New York, The Twentieth Century Fund.

24. Wooldridge, J. (2002), "Econometric Analysis of Cross Section and Panel Data", USA, MIT.

25. World Bank (2015), "World Bank Indicators", available at: http://data.worldbank.org/indicator (accessed June $1^{\text {st }} 2015$ ).

\section{About the author}

Ildiko Virag Neumann PhD works in Department of International Economics Institute of Economics Faculty of Economic Sciences in University of Pannonia Veszprém, Hungary. Research fields are: International Economics, international trade, European integration,EU enlargement to Central and Eastern Europe. The author can be contacted at ildiviragvirag@gmail.com 